\title{
EFFECT OF PIN PROFILES ON THE MECHANICAL PROPERTIES OF FRICTION-STIR-WELDED AA5383 AND AA7075
}

\author{
VPLIV OBLIKE TRNA NA MEHANSKE LASTNOSTI \\ VRTILNO-TORNO VARJENEGA AA5383 IN AA7075
}

\author{
Pandy Madhan Kumar ${ }^{1}$, Veerabathiran Anbumalar ${ }^{2 *}$ \\ ${ }^{1}$ Department of Mechanical Engineering, Sri Nandhanam College of Engineering and Technology, Tirupattur 635603, India \\ ${ }^{2}$ Department of Mechanical Engineering, Velammal College of Engineering and Technology, Rameswaram High Road, Madurai 625009, India
}

Prejem rokopisa - received: 2019-03-13; sprejem za objavo - accepted for publication: 2019-09-08

doi:10.17222/mit.2019.056

\begin{abstract}
Friction-stir welding (FSW) is an unyielding-state welding process developed by The Welding Institute, United Kingdom. FSW is mainly based on the tool geometry, process parameters and welding material. The tool geometry plays the principle role in obtaining desirable microstructures of the welds, improving the strength and fatigue resistance of the joints. Currently, friction-stir-welding tools are designed using the trial-and-error method. In this study, three different types of FSW tools are considered for the fabrication of butt joints from AA5383 and AA7075. Various tool profiles such as the cylindrical taper projection, cylindrical thread-pin projection and triangle-pin projection are considered in the present study. The pin profiles are assessed based on the weld quality during tensile tests and hardness tests conducted on welded samples. With the analysis, it is found that the triangular pin produces sound welds at an $800-\mathrm{min}^{-1}$ speed, $20-\mathrm{mm} / \mathrm{min}$ feed and $4-\mathrm{kN} \mathrm{load}$.

Keywords: friction-stir welding, microstructure, tool-pin profile, tensile strength, hardness
\end{abstract}

Vrtilno-torno varjenje (FSW) je proces varjenja, ki so ga razvili na Inštitutu za varjenje v Angliji. Potek in karakteristike FSW določajo predvsem geometrija orodja, procesni parametri varjenja in material, ki ga varimo. Geometrija trna orodja ima pomembno vlogo pri doseganju želene mikrostrukture zvara oz. pri izboljšanju trdnosti in odpornosti proti utrujanju varjenega spoja. Zaenkrat oblikovanje orodij za FSW temelji na metodi preizkus/napaka. V študiji so avtorji ocenjevali vpliv treh vrst trnov FSW orodja pri izdelavi zvarnih spojev med ploščami iz dveh Al zlitin: AA 5383 in AA7075. Uporabili so naslednje profilne geometrije trna orodij: cilindrično stožčasto, cilindrično z navojem in trikotno. Na osnovi nateznih preizkusov in merjenja trdote so ugotovili, da vse tri geometrije omogočajo izdelavo odličnih zvarnih spojev. Na osnovi izvedenih analiz so ugotovili, da s trikotnim profilom trna orodja lahko izdelajo dobre zvare pri hitrosti vrtenja orodja $800 \mathrm{~min}^{-1}$, njegovem pomiku $20 \mathrm{~mm} / \mathrm{min}$ in obremenitvi (sili) $4 \mathrm{kN}$.

Ključne besede: vrtilno-torno varjenje, mikrostruktura, profil trna orodja, natezna trdnost, trdota

\section{INTRODUCTION}

The friction-stir-welding technique is a non-consumable unyielding-phase welding, which permits an extensive scope of parts and geometries to be welded. W. Thomas and his social group at The Welding Institute, United Kingdom, conjured it in 1991. Friction-stir welding is used in modern industries such as shipbuilding, aerospace, automobile production and other modern manufacturing industries. It is frequently used for non-heat treatable or powder-metallurgy aluminium alloys, to which fusion welding cannot be applied. Thus, the weld mechanism and the relations between the microstructure, mechanical properties and process parameters have recently become fundamental studies. A detailed observation of the material microstructure in the joint section shows that there is an area located at the core of the weld, called "the nugget", where the original grain and sub-grain boundaries appear to be replaced with fine, equally recrystallized grains characterized by a nominal dimension of a few micrometers. Friction-stir

*Corresponding author's e-mail:

dranbumalarv@gmail.com (Anbumalar Veerabathiran) welding, a modern and an environment-friendly solidstate joining process is used for joining a family of relatively light materials, especially aluminium and its alloys.

The effectiveness of such a joint is strongly dependent on the geometry of the tool, process parameters and welding material. The tool geometric parameters, such as the height, the pin shape and the shoulder surface of the head, have a large influence on both the metal flow and the heat generation due to friction. ${ }^{28}$ During friction-stir welding, various stirrer geometries are used for producing AA6063-T1 butt joints. For this reason, we have to investigate the mechanical properties of a joint and compare them with the microstructure of the joint. It was reported that a rotational speed of $2000 \mathrm{~min}^{-1}$ and a welding speed ranging from $50 \mathrm{~mm} / \mathrm{min}$ to $200 \mathrm{~mm} / \mathrm{min}$ produced a good weld; mechanical properties such as the tensile strength and hardness of the joint were also investigated. ${ }^{20}$ The right-screw- and left-screw-geometry stirrer designs provide for a sound joint with no blemish in the weld metal, exhibiting an increased joint strength, better than that of an aluminium-based metal. ${ }^{7}$ Researchers also 
investigated the effects of the tool geometry on dissimilar friction-stir welding of polyethylene-polypropylene. ${ }^{18}$ Four different pin profiles, including threaded cylindrical, squared, triangular and straight cylindrical ones were considered. The interaction effects of welding variables, including the rotational speed and traverse speed were also studied. In order to control the material flow, the tools used were equipped with a stationary shoulder. ${ }^{14}$ Tensile tests and durometer hardness tests were carried out and a microstructure analysis was conducted for all welded joints. It was observed that the threaded-cylindrical-pin profile produced mechanically strong welded joints. ${ }^{15}$

Tool-pin profiles were also examined to determine the influence of the shoulder geometry on friction-stir welding of 1-mm copper-DHP plates. Tool welds were formed using three different shoulder geometries including flat, conical and scrolled ones at a varying traverse speed and rotation of the friction-stir-welding tool. The flat-shoulder tool proved to be insufficient for the welds because several defects were found in all the weld samples. On the other hand, the scrolled-shoulder tool is more effective than the conical one for the production of defect-free welds. However, both geometries require the lowest rotational speed to evade internal defects. At the same welding parameters, superior grain refinement, higher hardness and better strength are achieved in weld nuggets also by means of a scrolled FSW tool. ${ }^{12}$ Studies proved the influences of various rotational speeds and friction-stir-welding tool geometries on the macrostructure, microstructure and joint strength. Four tool-pin profiles (a conical-thread pin, a cylindrical conical-thread pin, a stepped conical-thread pin and a flared Triflute-pin tool) and two rotational speeds, $600 \mathrm{~min}^{-1}$ and $800 \mathrm{~min}^{-1}$, were used. The results indicated that the friction-stir-welding tool geometry considerably influences the material flow in the nugget zone and, consequently, the weld mechanical properties. ${ }^{26}$

The influence of the pin geometry on various properties of friction-stir-welded samples made with tools with different pin profiles was proved. In the case of four-flute cylindrical-pin profiles, friction-stir welding could not be performed on an aluminium alloy. ${ }^{5}$ It was found in a research that tool geometries such as the cylindrical geometry, cone geometry, left-screw geometry and right-screw geometry affect the weld properties at a welding speed of $50-200 \mathrm{~mm} / \mathrm{min}$ and rotational speed of $2000 \mathrm{~min}^{-1}$. The mechanical properties such as the tensile strength and hardness of a joint were also investigated and compared with the microstructure of the joint. The results show that the shapes of the left- and right-screw stirrer provided for sound joints with no voids in the weld metal and with an increased joint strength that was higher than that of the aluminiumbased metal. ${ }^{19}$
The effects of the shoulder geometry of a tool used for milling-machine friction-stir-welded joints of aluminium alloy 1100 on the microstructural evolution and mechanical properties were studied. Three designs of the shoulder geometry were evaluated to induce different distributions of thermal cycles in the welding regions. Thermal cycles were measured using thermocouples and a data acquisition system. The system results showed that the featured shoulder tools produced an important effect on the thermal cycles, generating a wide plasticized region and the biggest grain size in the stir zone when compared with the flat-shoulder tool. ${ }^{32}$ Researchers studied the production to forecast the ultimate tensile strength and hardness of the weld zone with and without tool profiles. The response-surface methodology deals with the movement of the material flow in friction-stir-welded aluminum alloy $6082 .{ }^{9}$

The effects of important welding parameters and tool properties that affect the static strength of the friction-stir spot welds of polymer sheets were determined. Different tool-pin profiles, pin lengths and pin angles were used to produce the joints. Based on the experiments, the effects of the pin profile, pin length, pin angle and tool rotational speed on the friction-stir spot-welding formation and weld strength were determined for a specific alloy. ${ }^{6}$ Improved heat-generating models for straight- and tapered-shoulder geometries with different tool-pin profiles for friction-stir welding were developed. They were developed by considering the welding process as a combination of pure sliding and pure sticking conditions. According to the results, the amount of heat generation is directly proportional to the number of edges in pin profiles so that the heat generated in the profiles increases from a triangular pin profile to a hexagonal pin profile. ${ }^{33}$ Experimental relationships among the process parameters such as the rotational speed, welding speed and axial force help us envisage the maximum tensile strength. In addition, statistical tools, such as the cylindrical-pin profile, are used for such investigations. ${ }^{4}$

In a study on the geometry and size effects of samples on the tensile properties of FSW AA 2024 joints, 2.5 times the tool shoulder is proposed for the gauge length. ${ }^{9}$ Different tool designs and their effects are investigated and it is concluded that the pin profile is related to the mechanical properties and the maximum tensile strength is achieved for the cylindrical-pin profile with an 8-mm diameter. ${ }^{34}$

Some studies also reported that samples made with a polygonal pin profile are hard and brittle in comparison with the cylindrical-pin-profile samples. ${ }^{22}$ There are studies on the effects of three different tool geometries and two joint geometries on the quality of AA 5083-H111 T welds made with friction stir welding (FSW). All the tools have concave shoulders with different pin geometries: a threaded taper pin, a quadrangular pyramidal and progressive pin, a partly threaded cylindrical and partly pyramidal pin. T-lap and T-butt joint 
configurations are also studied. The results show that no significant change in the hardness is observed with any combination of tool and joint geometries. The tensilestrength efficiency of the joints welded with the progressive-pin tool was found to achieve the optimum level. ${ }^{16}$

According to a study on the effects of tool design, new friction-stir-welding design features such as hollow, fluted and thermally insulated designs provide for a good welding thermal efficiency when compared to the conventional tool for aluminium welding. The effects of the tool-shoulder contact found during a thermal analysis of friction-stir welding are reported $i^{21}$. The results show that the tool shoulder has a remarkable effect on the mechanical properties of AA6082. Observation revealed that the heat generation is higher between the trailing edge and retreating side-leading edge corner in the counter-clockwise direction and lower between the retreating side and the trailing edge in the clockwise direction. The results show that the welds produced with a ridge shoulder tool exhibit superior properties with a significantly lower axial force. ${ }^{24}$

A literature review shows that the tool geometry is the most important parameter for achieving better welding with friction-stir welding. It also shows that the tool geometry is selected based on the material to be welded. In the present work, three different types of tool geometry are considered for joining dissimilar aluminium alloys AA7075 and AA5383.

\section{MATERIALS AND METHODS}

The welding materials used for modern investigations include aluminium alloys 5383 and 7075 whose chemical compositions are obtained using a vacuum spectrometer. Aluminium alloy AA5383, also called Alloy 5S, is the major alloying element. Magnesium and silicon are the chief alloying elements; treatable precipitationtoughened aluminium alloy AA7075 contains zinc as the major alloying element. ${ }^{27}$ Specimens of aluminium alloys AA7075 and AA5383 are used in the present study. The major alloying elements, magnesium and silicon, are found in precipitation-hardened aluminium alloy 7075 . It is one of the universally used aluminium alloys, formerly called the 7-series alloy.

Zinc as the most important alloying element is found in aluminium alloy AA5383. This alloy is strong and its

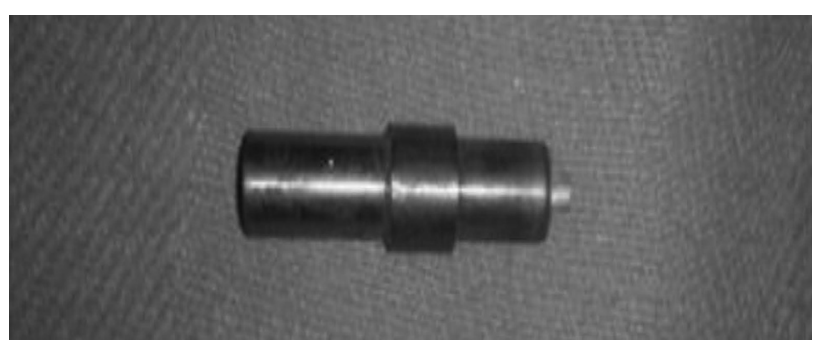

Figure 1: High-carbon high-chromium triangular tool-pin profile strength is comparable to many steels. It was formerly called the 5-series alloy. The material properties of this alloy include a good fatigue strength, standard machinability and resistance to corrosion, which is better than those of the other aluminium alloys. The two aluminium alloys are used for the research. The chemical compositions of AA7075 and AA5383 are shown in Table 1. They were analyzed with a vacuum spectrometer. ${ }^{29}$

Table 1: Chemical compositions (\%) of AA7075 and AA5383

\begin{tabular}{|c|c|c|}
\hline Alloy & AA7075 $(\%)$ & AA5383 $(\%)$ \\
\hline $\mathrm{Mg}$ & 2.374 & 4.237 \\
\hline $\mathrm{Mn}$ & 0.028 & 0.579 \\
\hline $\mathrm{Cu}$ & 1.564 & 0.012 \\
\hline $\mathrm{Cr}$ & 0.251 & 0.064 \\
\hline $\mathrm{Si}$ & 0.023 & 0.057 \\
\hline $\mathrm{Al}$ & 90.05 & 94.78 \\
\hline
\end{tabular}

\subsection{Tool material}

Tool steel is one of the commonly used frictionstir-welding tool materials, allowing a weld of up to 50 $\mathrm{mm}$. Here, welding deals with aluminium, copper and magnesium alloys. ${ }^{1}$ Tool materials exhibit excellent machinability and thermal-fatigue resistance. Tool steels might cause damage and deformation during friction-stir welding of aluminium alloys and other low-meltingtemperature materials. Tool steel can be used to weld both similar and dissimilar materials as lap joints or butt joints. During the welding using a butt-joint arrangement, a harder, high-carbon, high-chromium tool has a remarkably excellent wear resistance amongst different tool steels. H13 is characterized by shock and abrasion resistance combined with red hardness. A triangular tool-pin profile is shown in Figure 1.

This tool-pin profile has a high toughness and 5-\% chromium content. High-chromium stainless steel has a very high corrosion resistance. The softer material is on the retreating side and the tool material is on the advancing side and thus the tool is given a slight offset from the butt interface towards the softer material. ${ }^{25}$ Stainless steel, high-carbon high-chromium steel, highspeed steel, H13 and C40 materials have been joined with tool steels. This high-carbon, high-chromium-steel tool material is used in the present investigation and its chemical composition is given in Table 2. It is noted for its high dimensional stability in addition to a good wear resistance and excellent edge-holding capabilities.

Table 2: Chemical composition of $\mathrm{HCHCr}$

\begin{tabular}{|c|c|c|c|c|c|c|}
\hline Components & $\mathrm{C}$ & $\mathrm{Mg}$ & $\mathrm{Si}$ & $\mathrm{Ni}$ & $\mathrm{Mo}$ & $\mathrm{Cr}$ \\
\hline$w / \%$ & 97.67 & 0.97 & 0.19 & 0.25 & 0.80 & 0.12 \\
\hline
\end{tabular}

This composition hardens the material so that it can sustain the high temperature in the stir zone generated during friction stirring. The density of the material is $7.7-8.03 \mathrm{~g} / \mathrm{m}^{3}$, the melting point is $1426{ }^{\circ} \mathrm{C}$ and its 
elastic modulus is 190-210 GPa. Dies, cutters, measuring tools and finishing rolls for tier-mill sand punches are commonly made of high-carbon high-chromium steel. ${ }^{10}$ Plates of $50 \mathrm{~mm} \times 100 \mathrm{~mm}$ are machined and used as the specimens. The tool material used is $\mathrm{HCHCr}$, containing C, Mg, Si, Ni, Cr and Mo. These tools show high dimensional stability with added wear resistance coupled with excellent edge-holding qualities and, hence, they are selected for the present investigation. ${ }^{17}$ The welded blank of AA7075 and AA5383 can be used in the automotive sector as well as the aerospace industry where a high strength-to-weight ratio is the most desirable property. ${ }^{13}$

Aluminium alloys of the 7xxx and 5xxx series are not easily weldable with the conventional techniques. The electrical-resistance technique is also used to weld a few aluminium alloys. However, these techniques require an extensive surface preparation and prevention of an oxide formation, which is quite difficult and, thus, this limits their use to specific applications. ${ }^{8}$ The raw materials in the form of plates that are $50 \mathrm{~mm}$ wide, $100 \mathrm{~mm}$ long and $6 \mathrm{~mm}$ thick are machined using a milling machine to make them parallel. The clamping system of the friction-stir-welding machine, leading to uniformity of the gaps between the plates is of crucial importance. The thickness of the welding plates range from $0.5 \mathrm{~mm}$ to 10 $\mathrm{mm}$ and the experiments are carried out on the frictionstir-welding machine.

\subsection{Experimental set-up}

One of the most important aspects of FSW is the exploitation of a readily available vertical milling machine; friction-stir welding involves a large welding axial force of about $2500 \mathrm{kN}$ and a fixture with proper clamps is designed to prevent the movement of specimens. The friction-stir-welding machine has a capability of welding plates with a thickness of $0.5-10 \mathrm{~mm}$. Aluminium-alloy welded joints require a vertical head attachment, accommodating high spindle speeds that vary between $200 \mathrm{~min}^{-1}$ and $4000 \mathrm{~min}^{-1}$, powered by 22-kW AC motor and with axis-stroke length movements of $600 \mathrm{~mm}, 200 \mathrm{~mm}$ and $300 \mathrm{~mm}$ along the $\mathrm{x}, \mathrm{y}$ and $\mathrm{z}$ axes, producing professional tool-pin profiles. Frictionstir-welding process parameter called the traverse feed rate of the worktable is controlled by the automatic feed system of the milling machine. A FSW process requires

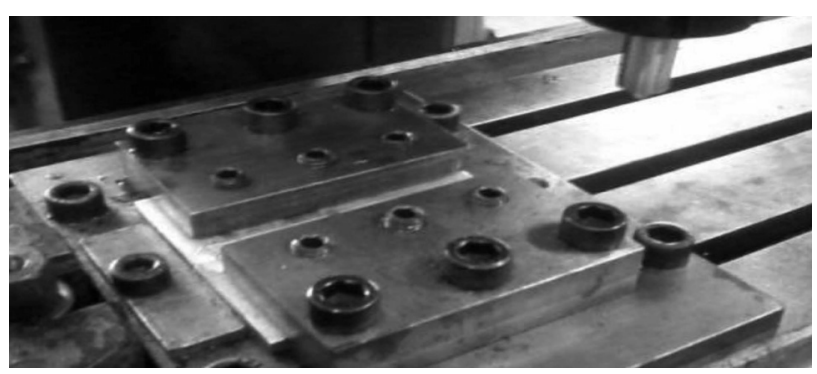

Figure 2: Fabricated friction-stir-welding machine fixtures a data acquisition system with suitable equipment for acquiring relevant parameters and monitoring the process.

Large forces that develop when a FSW tool pin plunges into a workpiece to be welded directly affect the base plate and cause the plates to drift apart. Hence, a rigid clamping fixture is essential to withstand the forces and prevent the extrusion of the plasticized material from the joint interface to the bottom of the joint. The thermal-expanding and buckling behavior that the plates encounter during normal FSW conditions can also be restrained by the clamping. In the present work, fixture components are fabricated from mild-steel plates.

The base plate is prepared using mild steel, having a size of $200 \mathrm{~mm} \times 160 \mathrm{~mm} \times 10 \mathrm{~mm}$ and it is machined precisely to hold the clamping plates and stopper plate for the AA5383 and AA7075 workpieces with a thickness of $6 \mathrm{~mm}$.

The friction-stir-welding tool and welding parameters play a very important role, determining the weld-joint characteristic. The experiment involving the major factors affecting friction-stir-welding parameters and tool design such as the tool rotational speed, welding speed and axial force are considered. Various parameters together with their ranges are selected and presented in Table 3.

The weld joints are prepared using the Computer Numerical Control software to maintain the consistency. The welds are made by joining both plates $(100 \times 50 \times 6)$ $\mathrm{mm}$ to make a weld joint with a width of $100 \mathrm{~mm}$ and a length of $100 \mathrm{~mm}$. Workpieces are clamped firmly on the machine table, with the backward tool tilted at an angle of $0^{\circ}$ throughout the length of the weld. The friction-stir weld is initiated by positioning the FSW tool in such a position that the tip of the pin just touches the upper surfaces of the workpieces.

Table 3: Optimum parameters for preparing a welded joint

\begin{tabular}{|c|c|c|c|}
\hline S. No. & $\begin{array}{c}\text { Axial load } \\
(\mathrm{kN})\end{array}$ & $\begin{array}{c}\text { Tool rotational } \\
\text { speed }\left(\mathrm{min}^{-1}\right)\end{array}$ & $\begin{array}{c}\text { Worktable feed } \\
(\mathrm{mm} / \mathrm{min})\end{array}$ \\
\hline 1 & 4 & 800 & 20 \\
\hline 2 & 5 & 1000 & 25 \\
\hline 3 & 6 & 1200 & 30 \\
\hline
\end{tabular}

\subsection{Tension test}

The weld is recognized and a two-inch mark is made to allow the measurement of the elongation before the test sample breaks under tension. ${ }^{2}$ The tensile test is performed according to the IS 1608:2005 specifications on the welded samples in a universal testing machine with a capacity of $100 \mathrm{kN}$. The tensile-test pieces are prepared and tested for each weld joint to ensure consistency and the data obtained for the welded specimens is shown on Figure 3. 


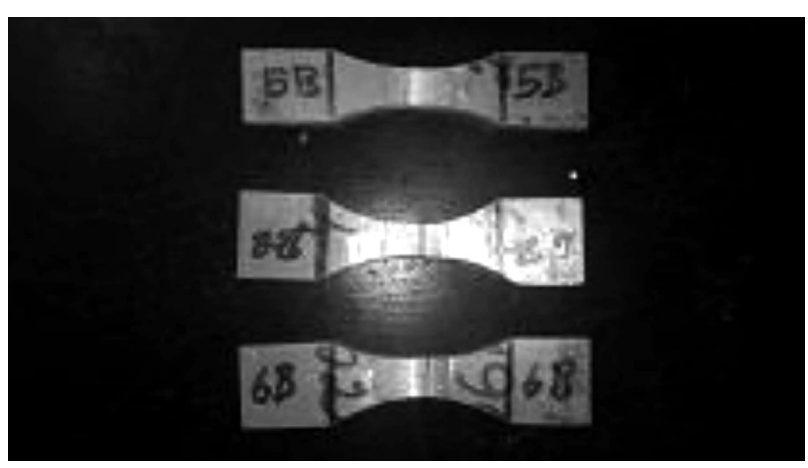

Figure 3: Tensile-test specimens

\subsection{Hardness test}

Hardness tests are conducted for both base plates, namely aluminum alloys AA5383 and AA7075 and also at the stir zone. To determine the effect of the temperature on friction-stir welding, the hardness of the welded stir zone is studied. The hardness of the welded specimen is estimated according to the Rockwell hardness ASTM E8 standard.

\section{RESULTS AND DISCUSSION}

The welded butt joints are tested mechanically by conducting an ultimate-tensile test and a hardness test used for identifying the best parameters and excellent friction-stir-welding tool-pin profile; welded joints are analyzed with a scanning electron microscope (SEM). In the present investigation, welding is done by maintaining both the welding speed and axial load as well as by varying the rotational speed and tool pin profiles individually. The welding is carried out for the two dissimilar aluminum alloys, namely AA7075 and AA5383, as shown in Figure 4.

\subsection{Tensile examination}

In the present work, the operation process parameters such as the worktable feed, axial load and tool rotational speed are considered; in addition, the triangle, cylindrical thread and cylindrical taper pins are used and their influence on the mechanical properties are investigated. The experiments conducted show that for the triangle-pin profile, the tensile strength obtained for an axial load of

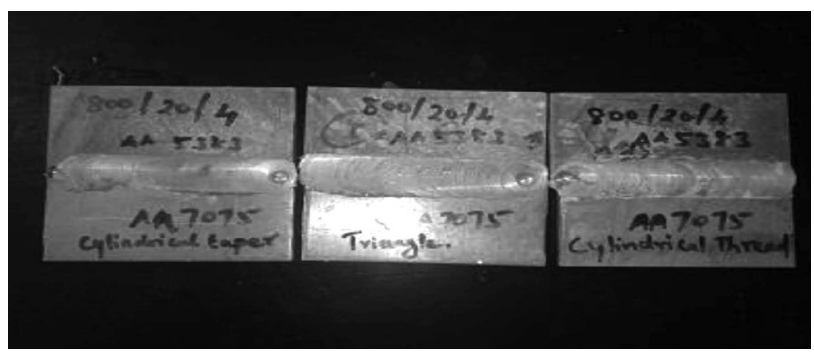

Figure 4: AA5383-AA7075 welded specimens

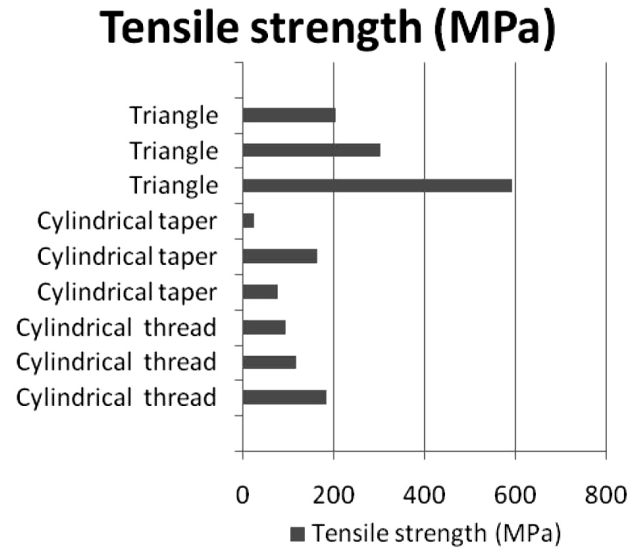

Figure 5: Tensile examination results

$4 \mathrm{kN}$ is $592 \mathrm{MPa}$. The tensile strength is decreased by $33 \%$ by increasing the axial load by $1 \mathrm{kN}$.

It can be concluded that the material has high strength when the axial load is low. In the case of cylindrical threaded tool, a similar observation can also be made as an increase in the axial load from $4 \mathrm{kN}$ to $6 \mathrm{kN}$ results in a decrease in the tensile strength from 183.1 $\mathrm{MPa}$ to $91.7 \mathrm{MPa}$. A similar observation is made for the cylindrical taper tool. The tensile-strength values observed for the cylindrical thread pin are $162.6 \mathrm{MPa}$, 75.1 MPa and 93.2 MPa for the loads of $4 \mathrm{kN}, 5 \mathrm{kN}$ and $6 \mathrm{kN}$, respectively Figure 5. Some researchers also used a square tool and reported a value of $211 \mathrm{MPa}$ for a 700- $\mathrm{min}^{-1}$ tensile strength when welding aluminum alloys AA5383 and AA7075. ${ }^{29}$ Similar tensile-strength values were obtained and reported for friction-stirwelded aluminum alloys.

\subsection{Hardness}

The hardness ordeal conducted on the welded samples are in table the hardness value of the weldments done using triangle pin profile such as $4 \mathrm{kN}$ is 72 from investigation triangle tool profile is effective when compared to the cylinder thread and cylindrical taper tool pin profile.

\section{Rockwell Hardness(HRB)}

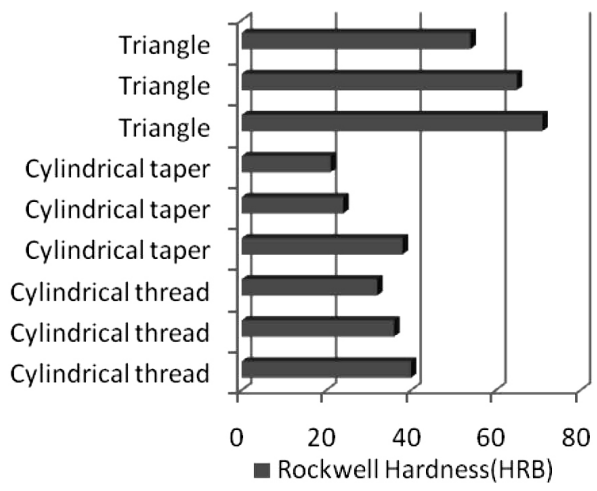

Figure 6: Hardness results 

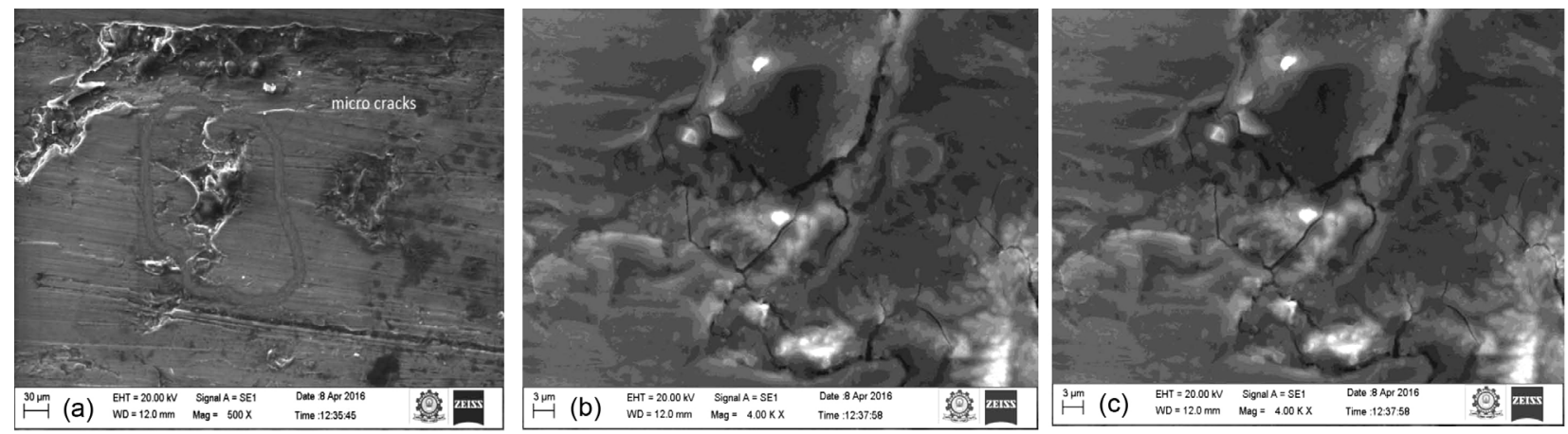

Figure 7: Microstructure observations of the stir zone of AA5383 and AA7075

Thus it can be concluded that mechanical properties of the welded samples the researchers using square tool is reported as $70 \mathrm{HRB}$ for $700 \mathrm{~min}^{-1}$ Rockwell hardness value of welded aluminum alloys 5383 and 7075 alloys. ${ }^{29}$ Similar kind of hardness values is obtained and researcher reported friction stir welded aluminium alloys.

Table 4: Hardness results

\begin{tabular}{|c|c|c|c|}
\hline S. No. & Pin profile & $\begin{array}{c}\text { Applied load } \\
(\mathrm{N})\end{array}$ & $\begin{array}{c}\text { Rockwell hard- } \\
\text { ness (HRB) }\end{array}$ \\
\hline 1 & Cylindrical thread & 980.665 & 40 \\
\hline 2 & Cylindrical thread & 980.665 & 36 \\
\hline 3 & Cylindrical thread & 980.665 & 32 \\
\hline 4 & Cylindrical taper & 980.665 & 38 \\
\hline 5 & Cylindrical taper & 980.665 & 24 \\
\hline 6 & Cylindrical taper & 980.665 & 21 \\
\hline 7 & Triangle & 980.665 & 71 \\
\hline 8 & Triangle & 980.665 & 65 \\
\hline
\end{tabular}

\subsection{Microstructure of AA7075 and AA5383}

The surface of the welded area exhibits uniform grains; it is smooth due to proper welding, maybe also due to the presence of new stir grains, improving the hardness of the welding zone. The region difficult to identify in the microstructure shows evidence of the stir-zone grain content in the main zone. The microstructure of the welded aluminum alloys shown in Figure 7 shows a proper and uniform fusion of the materials because of the high temperature in the heated zone.

In the stir zone, we recognize a very increasing hardness value of the welded samples. The welding progression is homogeneous and controllable. As seen in the figure, due to the result of the welding progression, bumpy surfaces developed, proving that small weld burrs can be observed on dissimilar aluminium alloys 5383 and 7075. In the weld-stir zone, small microcracks can be observed, which may be a result of the friction-stirwelding tool-pin profile.

\section{CONCLUSIONS}

In this present investigation, FSW of AA5383 and AA7075 dissimilar joints was successfully accomplished using different parameters, namely the welding speed, axial load, tool rotational speed and tool-pin profile. The weld quality at various tool rotational speeds, axial loads and welding-table feeds was studied, with a special emphasis on the tool-pin profile. Based on the tool-pin profiles and their influence on the mechanical properties, it is found that the triangle-pin profile provides for better mechanical properties than the cylindrical taper and cylindrical thread-pin profiles. It is concluded that a tool rotational speed of $800 \mathrm{~min}^{-1}$, together with a $20-\mathrm{mm} / \mathrm{min}$ transverse feed and $4-\mathrm{kN}$ axial load, gives excellent tensile strength and a hardness value of 592 MPa.

\section{REFERENCES}

${ }^{1}$ J. Q. Su, T. W. Nelson, R. Mishra, M. Mahoney, Friction Stir Processing of Aluminum Alloy,Acta Materialia, 51 (2003), 713-729

${ }^{2}$ K. P. Mehta, V. J. Badheka, Influence of tool pin design on properties of dissimilar copper to aluminum friction stir welding, Transactions of Nonferrous Metals Society of China, 27 (2017), 36-54

${ }^{3}$ H. J. Chauhan, A. Chouhan, S. L. Meena, Experimental investigation and non destructive testing of friction stir welded aluminium alloy AA 6082 using tool with and without shoulder geometry, International Research Journal of Engineering and Technology, 3 (2016), 2656-2664

${ }^{4}$ F. Lambiase, A. Paoletti, A. Diilio, Effect of tool geometry on mechanical behavior of friction stir spot welds of polycarbonate sheets, The International Journal of Advanced Manufacturing Technology, 88 (2017), 3005-3016

${ }^{5}$ J. S. Jesus, M. Gruppelaar, J. M. Costa, A. Loureiro, J. A. M. Ferreira, Effect of geometrical parameters on friction stir welding of AA 5083-H111 T-joints, Procedia Structural Integrity, (2016), 242-248

${ }^{6}$ R. John, K. V. Jata, K. Sadananda, Residual stress effects on near threshold fatigue crack growth in friction stir welded aerospace alloys, International Journal of Fatigue 25, (2003), 939-948

${ }^{7}$ M. R. Hajideh, M. Farahani, S. A. DavoudAlavi, N. M. Ramezani, Investigation on the effects of tool geometry on the microstructure and the mechanical properties of dissimilar friction stir welded polyethylene and polypropylene sheets, Journal of Manufacturing Processes, 26 (2017), 269-279 


\section{P. M. KUMAR et al.: EFFECT OF PIN PROFILES ON THE MECHANICAL PROPERTIES OF FRICTION-STIR-WELDED ...}

${ }^{8}$ I. Shigematsu, Y. J. Kwon, K. Suzuki, T. Imai, N. Saito, Joining of 5083 and 6061 aluminum alloys by friction stir welding, Journal of Material Science Letters, 22 (2003), 353-356

${ }^{9}$ G. Buffa, J. Hua, R. Shivpuri, L. Fratini, Design of the friction stir welding tool using the continuum based FEM model, Materials Science and Engineering A, 419, (2006), 381-388

${ }^{10}$ H. Li, J. Gao, Q. Li, A. Galloway, A. Toumpis, Effect of friction stir welding tool design on welding thermal efficiency, Science and Technology of Welding and Joining, (2018), 1-7

${ }^{11}$ Z. Zhang, W. Li, F. Wang, J. Li, Sample geometry and size effects on tensile properties of friction stir welded AA2024 joints, Materials Letters, 162 (2016), 94-96

${ }^{12}$ A. Dorbane, B. Mansoor, G. Ayoub, V. C. Shunmugasamy, A. Imad, Mechanical, microstructural and fracture properties of dissimilarwelds produced by friction stir welding of AZ31B and Al6061, Materials Science and Engineering: A, 651 (2016), 720-733

${ }^{13}$ P. Cavaliere, E. Cerri, L. Marzoli, J. Dos Santos, Friction stir welding of ceramic particle reinforced aluminium based metal matrix composites, Applied Composite Materials, 11 (2004), 247-258

${ }^{14}$ J. Unfried-Silgado, A. Torres-Ardila, J. C. Carrasco-García, J.Rodríguez-Fernández, Effects of shoulder geometry of tool on microstructure and mechanical properties of friction stir welded joints of AA1100 aluminum alloy, DYNA, 84 (2016), 202-208

${ }^{15}$ M. K. Bilici, A. I. Yükler, M. Kurtulmu', Influence of Tool Pin Geometry in Friction Stir Spot Welded Polymer Sheets, Journal of Scientific and Engineering Research, 3 (2016), 15-22

${ }^{16}$ M. A. Waheed, L. O. Jayesimi, S. O. Ismail, O. U Dairo, Modeling of heat generations for different tool profiles in friction stir welding: study of tool geometry and contact conditions, Journal of Applied and Computational Mechanics, 3 (2017), 37-59

${ }^{17}$ K. K. Mugada, K. Adepu, Role of Tool Shoulder End Features on Friction Stir Weld Characteristics of 6082 Aluminum Alloy, Journal of The Institution of Engineers Series C, (2018), 1-8

${ }^{18}$ J. R. Kim, E. Y. Ahn, H. Das, Y. H. Jeong, S. T. Hong, M. Miles, K. J. Lee, Effect of tool geometry and process parameters on mechanical properties of friction stir spot welded dissimilar aluminum alloys, International Journal of Precision Engineering and Manufacturing, 18 (2017), 445-452

${ }^{19}$ R. S. Mishra, Friction stir welding and processing, Materials Science and Engineering, R: Reports, 50 (2005), 1-78

${ }^{20}$ E. Sabari, M. Jahazi, A. Khodabandeh, H. Ghasemi-Nanesa, Influence of tool geometry and rotational speed on mechanical properties and defect formation in friction stir lap welded 5456 aluminum alloy sheets, Materials \& Design, 54 (2014), 381-389

${ }^{21}$ S. Sivachidambaram, G. Rajamurugan, D. Amirtharaj, Optimizing the parameters for friction stir welding of dissimilar aluminium alloys AA5383/AA7075, ARPN J. Eng. Appl. Sci., 10, (2015), 5434-5437

${ }^{22}$ W. M. Thomas, E. D. Nicholas, J. C. Needham, M. G. Murth, Friction Stir Butt Welding, International Patent Application, (1995), No. PCT/GB92/02203

${ }^{23}$ A. Meilinger, I. Torok, The importance of friction stir welding tool, Production Processes and Systems, 6 (2013), 25-34

${ }^{24}$ M. T. S. M. Said, D. A. Hamid, A. Ismail, M. A. Rojan, M. J. Zainuddin, The Effect of Pin Size on Friction Stir Welded AA5083 Plate Lap Joint, Automobiles and Mechanical Engineering, (2015), 85-92

${ }^{25}$ I. Galvao, R. M. Leal, D. M. Rodrigues, A. Loureiro, Influence of tool shoulder geometry on properties of friction stir welds in thin copper sheets, Journal of Materials Processing Technology, 13 (2013), 129-135

${ }^{26}$ K. Kimapong, J. Kaewwichit, W. Roybang, P. Poonnayom, S. Chantasri, Friction Stir Welding Tool Geometries Affecting Tensile Strength of AA6063-T1 Aluminum Alloy Butt Joint, International Journal of Advanced Smart Convergence, 4 (2015), 145-153

${ }^{27}$ A. Heidarzadeh, H. Khodaverdizadeh, A. Mahmoudi, E. Nazari, Tensile behavior of friction stir welded AA 6061-T4 aluminum alloy joints, Materials \& Design, 37 (2012), 166-173

${ }^{28} \mathrm{~K}$. Chiteka, Friction stir welding/processing tool materials and selection, (2011)

${ }^{29}$ N. Babu, N. Karunakaran, V. Balasubramanian, A study to estimate the tensile strength of friction stir welded AA 5059 aluminium alloy joints, The International Journal of Advanced Manufacturing Technology, 93 (2017), 1-9

${ }^{30}$ M. Bahrami, M. K. B. Givi, K. Dehghani, N. Parvin, On the role of pin geometry in microstructure and mechanical properties of AA7075/SiC nano-composite fabricated by friction stir welding technique, Materials \& Design, 53 (2014), 519-527

${ }^{31}$ M. Guerra, C. Schmidt, J. C. McClure, L. E. Murr, A. C. Nunes, Flow patterns during friction stir welding, Materials Characterization, 49 (2003), 95-101

${ }^{32}$ R. Rai, A. De, H. K. D. H. Bhadeshia, T. DebRoy, Review: friction stir welding tools, Science and Technology of Welding and Joining, 16 (2011), 325-329 